Article

\title{
Oxidizing Roasting Behavior and Leaching Performance for the Recovery of Spent $\mathrm{LiFePO}_{4}$ Batteries
}

\author{
Yafei Jie ${ }^{1}$, Shenghai Yang ${ }^{1}$, Yun Li ${ }^{1,2}$, Duoqiang Zhao ${ }^{1}$, Yanqing Lai ${ }^{1}$ and Yongming Chen ${ }^{1, *}$ \\ 1 School of Metallurgy and Environment, Central South University, Changsha 410083, China; \\ yafeijie1221@126.com (Y.J.); yangsh@mail.csu.edu.cn (S.Y.); li-yun@csu.edu.cn (Y.L.); \\ zhdq11261987@163.com (D.Z.); laiyanqing@csu.edu.cn (Y.L.) \\ 2 Department of Chemical and Metallurgical Engineering, School of Chemical Engineering, Aalto University, \\ 02150 Espoo, Finland \\ * Correspondence: csuchenyongming@163.com; Tel./Fax: +86-731-8883-0470
}

Received: 19 September 2020; Accepted: 22 October 2020; Published: 25 October 2020

\begin{abstract}
In this study, the effects of oxidizing roasting process on the liberation of cathode materials from $\mathrm{Al}$ foil under different conditions were investigated systematically. The mineralogical characteristics of the cathode materials before and after thermal treatment were extensively characterized using scanning electron microscopy (SEM) with energy dispersive spectroscopy (EDS), X-ray diffraction (XRD) as well as Fourier transform infrared (FT-IR) spectroscopy and X-ray photoelectron spectroscopy (XPS). The results indicated that the increase in roasting temperature, oxygen concentration, and air flow rate enhanced the liberation of cathode materials. The cathode materials were gradually oxidized to $\mathrm{Li}_{3} \mathrm{Fe}_{2}\left(\mathrm{PO}_{4}\right)_{3}$ and $\mathrm{Fe}_{2} \mathrm{O}_{3}$. Further, the carbon and fluorine content in the cathode materials decreased slowly during the thermal treatment, while the $\mathrm{Al}$ content increased. When the roasting temperature exceeded the melting point of $\mathrm{Al}$, the $\mathrm{Al}$ foils were ablated and the cathode materials adhered to the $\mathrm{Al}$ foils again, resulting in difficulty in separation. The cathode materials leaching performance test results demonstrated that the oxidation of cathode materials had a negative effect on the leaching of Fe in sulfuric acid leaching system.
\end{abstract}

Keywords: spent $\mathrm{LiFePO}_{4}$ batteries; oxidizing roasting; sulfuric acid leaching; cathode materials

\section{Introduction}

Lithium iron phosphate batteries (LFPBs) have drawn tremendous attention in recent years for new energy vehicle applications, due to their inherent advantages of long lifecycle and high safety but low cost [1,2]. In China, the main power batteries for public transportation are LFPBs [3]. Not surprisingly, therefore, the number of retired LFPBs is also enormous as witnessed by their rapid growth in 2018. There is a great possibility that LFPBs will dominate the retired batteries by 2020 [4]. LFPBs are claimed to be the clean energy sources of the future, but they still contain metals, lithium salts (mainly $\mathrm{LIPF}_{6}$ ), organic electrolyte, and plastics [5,6], which utilize non-renewable resources and can potentially damage the environment. Therefore, recycling spent LFPBs efficiently and in an environmentally friendly manner becomes critical and inevitable.

So far, two main methods are embraced to recycle spent lithium-ion batteries (LIBs): pyrometallurgy process and hydrometallurgy process [7]. Pyrometallurgy process is known for its simplicity, large throughput, and extensive applicability of raw materials. Hence, it is commonly adopted by some foreign companies (Umicore, SONY, OnTo, Accurec, Inmetco, Xstrata, etc.) [8,9]. However, it suffers from drawbacks including a large investment in fixed assets, high energy consumption, and hazardous gases (e.g., dioxins, furans, etc.) emission [7]. Moreover, pyrometallurgy process cannot work alone 
and must be combined with hydrometallurgy process when it comes to recycling valuable metals from multicomponent alloys.

Hydrometallurgy process, in contrast, gains the upper hand in recycling spent LIBs due to its high extraction rate, little noxious gas emission, low energy consumption, and low capital cost [10]. Thus, applying hydrometallurgy process to recycle spent LIBs appears to be more beneficial and companies like BRUNP, GEM, and Ganfeng Lithium have put it into practice [11]. Hydrometallurgy process mainly comprises of pretreatment, leaching, purification, separation, and product preparation. Pretreatment is an essential process with multiple benefits. Simply put, it can decrease scrap volume, separate battery components, and enrich valuable metals [12]. Based on the separation technologies, it can be divided into mechanical separation [13-15], organic reagent dissolution [16-19], alkali solution dissolution [20-23], and thermal treatment [24-26]. Among them, thermal treatment is considered the most efficient method to remove conducting reagent and organic binder, as well as to separate cathode materials since it is simple, convenient, and scalable. Several thermal treatment processes have been developed for pretreatment in literature, but only involving different operating temperatures. Yue Yang et al. [27] found that the temperature of thermal treatment must be controlled at above $550{ }^{\circ} \mathrm{C}$ but below the melt point of the $\mathrm{Al}$ foils of $650{ }^{\circ} \mathrm{C}$. Lee et al. [28] proposed a combination of mechanical and thermal treatment method to separate electrode materials. The XRD patterns of cathode materials indicated that carbon and binder were burnt off above $800{ }^{\circ} \mathrm{C}$. Rujuan Zheng et al. [29] investigated the effects of thermal treatment on spent $\mathrm{LiFePO}_{4}$ electrodes, and concluded that the optimum temperature was $600{ }^{\circ} \mathrm{C}$. Although oxygen concentration and air flow have a crucial effect on the oxidizing roasting process, little research has been thoroughly conducted on the aspect before, let alone the influence of process conditions on the $\mathrm{P}, \mathrm{Fe}, \mathrm{Li}, \mathrm{C}, \mathrm{F}$, and $\mathrm{Al}$ content of cathode materials or the leaching performance of cathode power in sulfuric acid system.

In this study, using spent $\mathrm{LiFePO}_{4}$ cathode plates as raw materials, oxidizing roasting was conducted to achieve efficient separation of cathode materials and $\mathrm{Al}$ foils. The effects of process conditions (roasting temperature, oxygen concentration, air flow rate, etc.) on the recovery efficiency, impurities content, phase composition, and leaching performance of cathode materials in sulfuric acid system, as well as the morphology of $\mathrm{Al}$ foils, were investigated in detail.

\section{Materials and Methods}

Spent LFPBs offered by ZhongTian Energy Storage Technology Co., Ltd. in China were used in the experiments. The flowsheet of the experimental procedures for the recovery of spent $\mathrm{LiFePO}_{4}$ cathode plates is described in Figure 1.

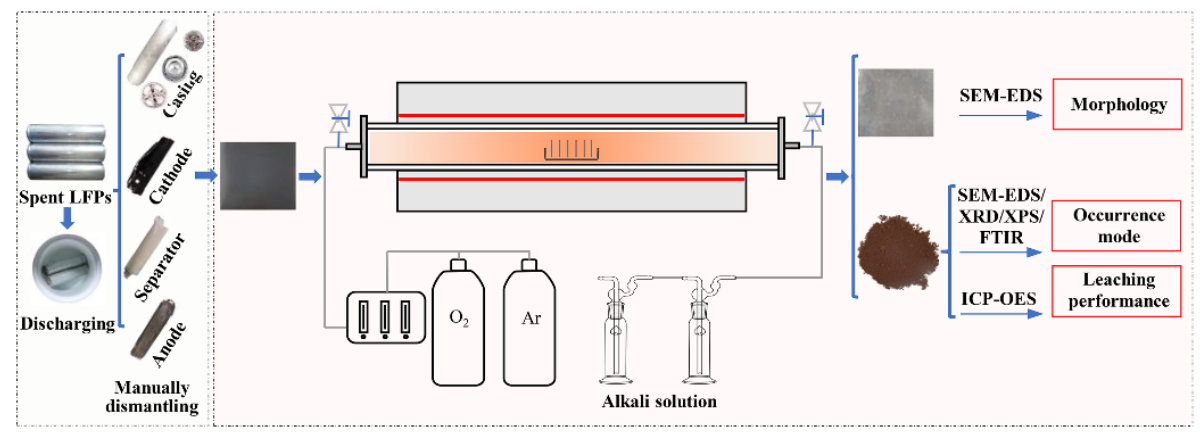

Figure 1. Flowsheet of the experimental process for the recovery of spent LFPBs cathode plates.

Prior to the oxidizing roasting experiments, a series of pretreatments were taken: First, a $10 \mathrm{wt} \%$ $\mathrm{NaCl}$ solution was prepared to discharge the remaining capacity for $24 \mathrm{~h}$ to prevent the potential dangers of self-ignition and short circuiting [30]; second, the discharged batteries were dismantled to obtain separated cathode plates; third, the cathode plates were further cut into small pieces $(5 \mathrm{~cm} \times$ $5.5 \mathrm{~cm}$ ). Table 1 presents the chemical composition of the raw cathode materials separated from $\mathrm{Al}$ 
foils. It is observed from Table 1 that the cathode materials contain $14.49 \% \mathrm{P}, 35.11 \% \mathrm{Fe}, 3.43 \% \mathrm{Li}$, $13.52 \% \mathrm{C}$, and $3.51 \% \mathrm{~F}$. The XRD pattern of the raw cathode materials shows that the cathode materials only contained $\mathrm{LiFePO}_{4}$ phase (Figure 2).

Table 1. Chemical composition of raw cathode materials.

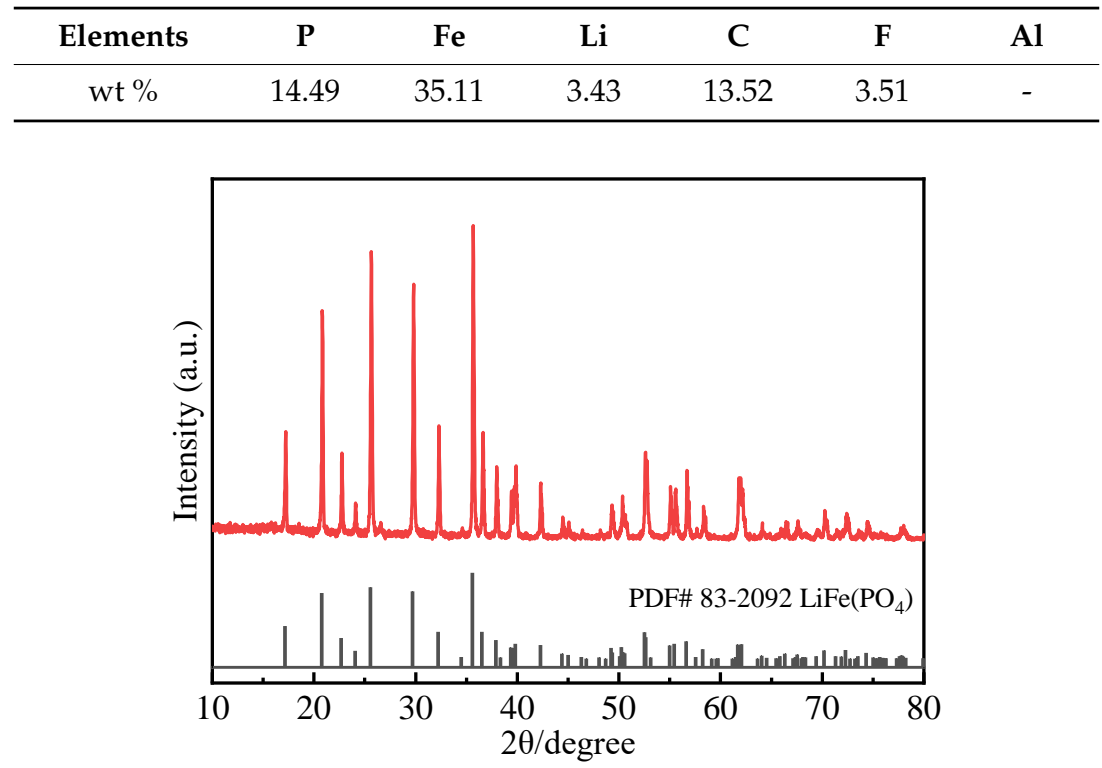

Figure 2. XRD pattern of the raw cathode materials.

The experiments of oxidizing roasting were implemented in a tube furnace (GSL-1400X, HF-Kejing, Hefei Kejing materials technology Co., Ltd., Hefei, China) equipped with an atmosphere controller. Six cathode plates were put into a special corundum ark in each experiment, which was then laid into a tubular furnace. The experiments were performed with a preset temperature $\left(450-700{ }^{\circ} \mathrm{C}\right)$ at a heating rate of $10{ }^{\circ} \mathrm{C} / \mathrm{min}$, gas flow (20-450 $\left.\mathrm{mL} / \mathrm{min}\right)$, and oxygen concentration $\left(0-50 \mathrm{vol} . \% \mathrm{O}_{2}\right)$. When the oxidizing roasting finished, the cathode plates were taken out, weighted and sieved for $10 \mathrm{~s}$. The cathode materials were then collected and ground by a planetary ball mill. To study the oxidizing roasting behavior of spent $\mathrm{LiFePO}_{4}$ cathode materials, various characterization methods were applied. The detailed information about the analysis methods is shown in Appendix A.

The leaching performance tests of calcined cathode materials were conducted in a $50 \mathrm{~mL}$ conical flask placed in a homoeothermic water bath. The conditions for sulfuric acid leaching system include $\mathrm{H}_{2} \mathrm{SO}_{4}$ concentration of $1 \mathrm{M}$, leaching temperature of $70{ }^{\circ} \mathrm{C}$, and solid-liquid ratio of $25 \mathrm{~g} \cdot \mathrm{L}^{-1}$. The solution was filtered after $1 \mathrm{~h}$ and the filtrate was analyzed by inductively coupled plasma-atomic emission spectroscopy (ICP-AES) in order to investigate the elemental content of Fe and Li. The residue was washed with ultrapure water and then analyzed by XRD.

In this study, the weight loss rate $W L_{M}$ of cathode plates was calculated as follows:

$$
W L_{M}=\frac{m_{0}-m_{1}}{m_{0}} \times 100 \%
$$

where $m_{1}(\mathrm{~g})$ is the mass of the cathode plates after thermal treatment and $m_{0}(\mathrm{~g})$ is the total mass of raw cathode plates.

The recovery rate $W R_{M}$ of the cathode materials was described as follows:

$$
W R_{M}=\frac{m_{2}}{m_{L}} \times 100 \%
$$

where $m_{2}(\mathrm{~g})$ is the mass of cathode materials recovered by thermal treatment and $m_{L}(\mathrm{~g})$ is the total mass of cathode materials. 
The leaching rate $\eta_{i}$ of metals from the cathode powder was obtained as follows:

$$
\eta_{i}=\frac{c_{i} V}{m_{3} w_{i}} \times 100 \%
$$

where $c_{i}\left(\mathrm{~g} \cdot \mathrm{L}^{-1}\right)$ represents the concentration of element " $i$ ", $V(\mathrm{~L})$ represents the volume of leachate; $m_{3}(\mathrm{~g})$ is the total mass of cathode powder and $w_{i}$ is the weight content of element " $i$ ".

\section{Results and Discussion}

\subsection{Effect of Roasting Temperature}

To investigate the effect of roasting temperatures on the oxidizing roasting process of spent $\mathrm{LiFePO}_{4}$ cathode plates, the experiments were carried out with increasing temperatures from 450 to $700{ }^{\circ} \mathrm{C}$ in steps of $50{ }^{\circ} \mathrm{C}$. A constant air flow rate of $300 \mathrm{~mL} / \mathrm{min}$ and a roasting time of $30 \mathrm{~min}$ were used. The results (shown in Figure 3) clearly indicate that the rise of temperature affects the oxidizing roasting of spent cathode plates significantly.
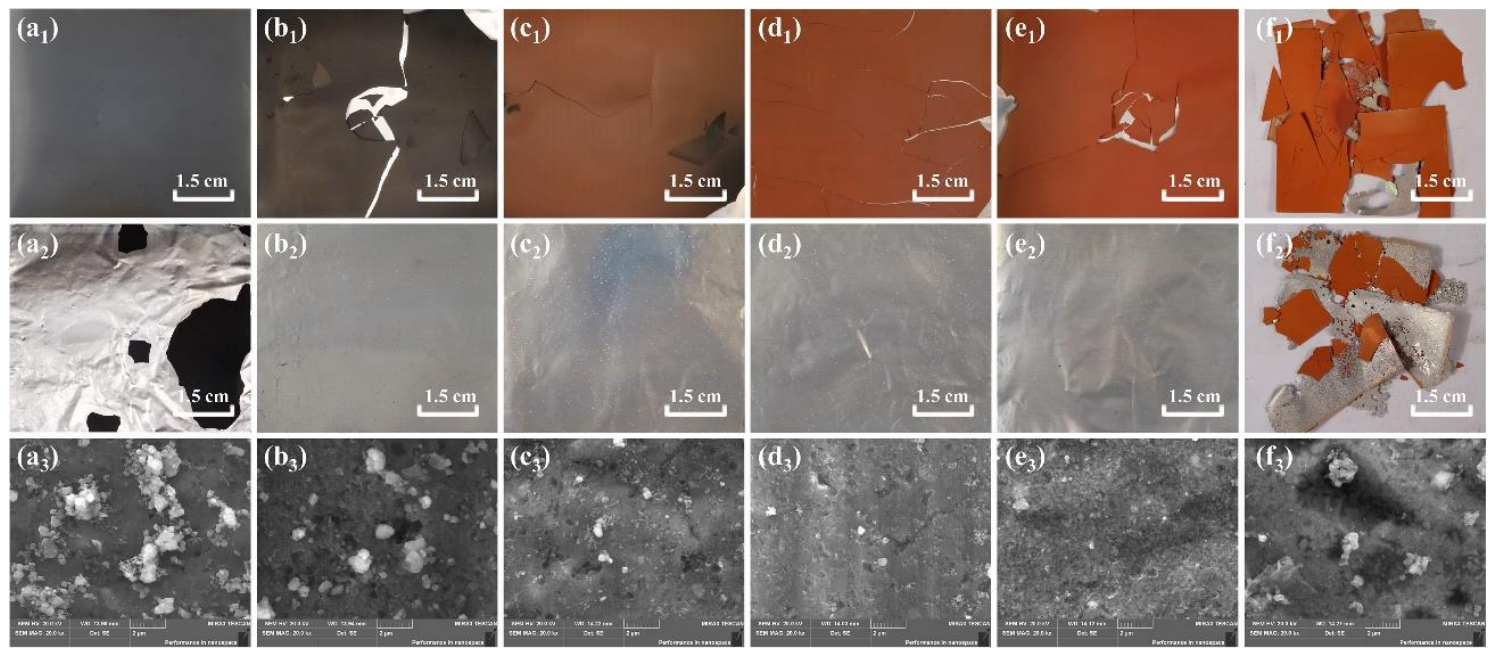

Figure 3. Effect of roasting temperature on spent $\mathrm{LiFePO}_{4}$ cathode plates. $\left(\mathbf{a}_{\mathbf{1}}-\mathbf{f}_{\mathbf{1}}\right)$ images of cathode plates at $450-700{ }^{\circ} \mathrm{C} ;\left(\mathbf{a}_{2}-\mathbf{f}_{2}\right)$ images of Al foils at $450-700{ }^{\circ} \mathrm{C} ;\left(\mathbf{a}_{3}-\mathbf{f}_{3}\right)$ SEM images of Al foils at $450-700{ }^{\circ} \mathrm{C}$.

Figure $3 \mathrm{a}_{1}-\mathrm{f}_{1}$ present the visual color change of cathode materials, from grey to brick red, as temperature increases. This can be attributed to the oxidation of $\mathrm{Fe}^{2+}$ to $\mathrm{Fe}^{3+}$ during the oxidizing roasting process [29]. The corresponding changes of $\mathrm{Al}$ foils obtained by screening can be observed in Figure $3 a_{2}-f_{2}$. At a roasting temperature of $450{ }^{\circ} \mathrm{C}$, there were a small number of cathode materials adhered to the $\mathrm{Al}$ foils, suggesting that the binder was not completely decomposed. At higher roasting temperatures $\left(500{ }^{\circ} \mathrm{C}\right.$ to $\left.650{ }^{\circ} \mathrm{C}\right)$, the cathode materials were entirely stripped off from the $\mathrm{Al}$ foils. However, at $700{ }^{\circ} \mathrm{C}$, the $\mathrm{Al}$ foils were ablated and holes could be noticed. At this temperature, the cathode materials adhered to the $\mathrm{Al}$ foils again and were difficult to be separated since the latter melted (the melting point of $\mathrm{Al}$ is $660^{\circ} \mathrm{C}$ ). The morphology of $\mathrm{Al}$ foils treated at different temperatures was analyzed by SEM (shown in Figure $3 a_{3}-f_{3}$ ). The SEM images indicate that the amount of binder PVDF and cathode materials adhered to the $\mathrm{Al}$ foils decreased gradually with increase in roasting temperature. Correspondingly, the surface corrosion and unevenness of the $\mathrm{Al}$ foils increased. This can be attributed to the effective oxidative decomposition of binder PVDF during the higher temperature oxidizing roasting process, which released fluorine-containing gases such as hydrogen fluoride (HF), that could corrode the $\mathrm{Al}$ foils [31].

Figure 4 presents the recovery efficiency of cathode materials, weight loss rate of spent $\mathrm{LiFePO}_{4}$ cathode plates and element content in calcined cathode materials at different roasting temperatures. 
It corresponded to the peeling of cathode materials in Figure $3 a_{2}-f_{2}$, respectively. The recovery efficiency of cathode materials increased from $77.0 \%$ to $99.9 \%$ and then dropped to $81.0 \%$ at $450-700{ }^{\circ} \mathrm{C}$. In addition, the weight loss rate of spent $\mathrm{LiFePO}_{4}$ cathode plates at different roasting temperatures was also obtained using Equation (1). It is evident that the roasting temperature has a significant influence on the weight loss rate of spent $\mathrm{LiFePO}_{4}$ cathode plates. The weight loss rate increased from $11.0 \%$ to $13.9 \%$ as the roasting temperature rose from $450{ }^{\circ} \mathrm{C}$ to $600{ }^{\circ} \mathrm{C}$. However, when the roasting temperature was over $600{ }^{\circ} \mathrm{C}$, the weight loss rate saturated around $14.0 \%$, implying that the binder was almost completely decomposed. To further study the effects of roasting temperature on cathode materials, the content of P, Fe, Li, C, F, and Al was measured (Figure 4b). The detailed information about the chemical analysis results of calcined cathode materials is shown in Appendix A, Figure A1. It can be observed in Figure A1 that with the increasing roasting temperature during the thermal treatment, the content of $\mathrm{P}, \mathrm{Fe}$ and Li fluctuated around $18.0 \%, 33.0 \%$ and $4.0 \%$, respectively, while the content of C, F, and $\mathrm{Al}$ showed obvious changes with the increase of roasting temperature. The $\mathrm{C}$ and $\mathrm{F}$ content showed a sharp decrease in the temperature range of $450-600{ }^{\circ} \mathrm{C}$, reducing from $4.58 \%, 0.24 \%$ to $0.85 \%, 0.052 \%$, respectively. This can be attributed to the rapid decomposition of organic matter. The $\mathrm{C}$ and $\mathrm{F}$ content was stable from $600{ }^{\circ} \mathrm{C}$ to $700{ }^{\circ} \mathrm{C}$, indicating the organic matter was almost completely decomposed. Nevertheless, the $\mathrm{Al}$ content showed a different behavior at $450-650{ }^{\circ} \mathrm{C}$. As the roasting temperature rose, the $\mathrm{Al}$ content in cathode materials went up from $0.038 \%$ to $0.052 \%$ slowly, due to the corrosion of $\mathrm{Al}$ foils caused by fluorine-containing gases. It surged to $1.23 \%$ at $700{ }^{\circ} \mathrm{C}$ since the melting of $\mathrm{Al}$ foils introduced $\mathrm{Al}$ chips into the cathode powder.
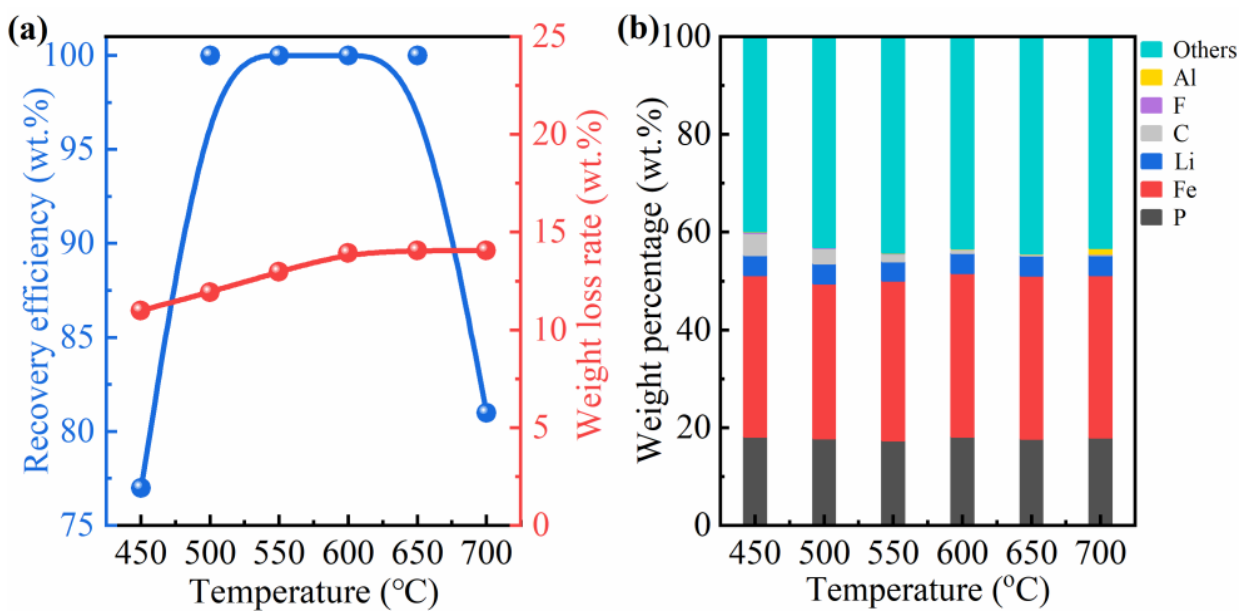

Figure 4. Effect of roasting temperature on the (a) recovery efficiency of cathode materials, weight loss rate of cathode plates and $(\mathbf{b})$ element content in calcined cathode materials.

The leaching behavior of cathode materials obtained from different roasting temperatures was analyzed by obtaining the leaching efficiency and phase transition using ICP-OES and XRD, respectively.

The leaching behavior of Fe and $\mathrm{Li}$ in sulfuric acid leaching system are shown in Figure 5a. The roasting temperatures, in the range of $450-700^{\circ} \mathrm{C}$, hardly affected the leaching efficiency of Li, which remained above $97 \%$, because lithium ions inserted in electrode materials are easily released from the Fe-P-O framework as they have higher reactivity than other metals in dilute sulfuric acid solution $[32,33]$. On the contrary, it significantly impacted the leaching behavior of Fe. The leaching efficiency of Fe was $96.6 \%$ at $450{ }^{\circ} \mathrm{C}$, but decreased to $73.02 \%$ when the temperature increased to $700{ }^{\circ} \mathrm{C}$. Considering these results, it can be extrapolated that the rise of roasting temperature accelerated the oxidation of $\mathrm{LiFePO}_{4}$ cathode materials. During this period, a large amount of $\mathrm{Fe}_{2} \mathrm{O}_{3}$ was produced, resulting in the decrease in amount of Fe leached by dilute sulfuric acid leaching system. 

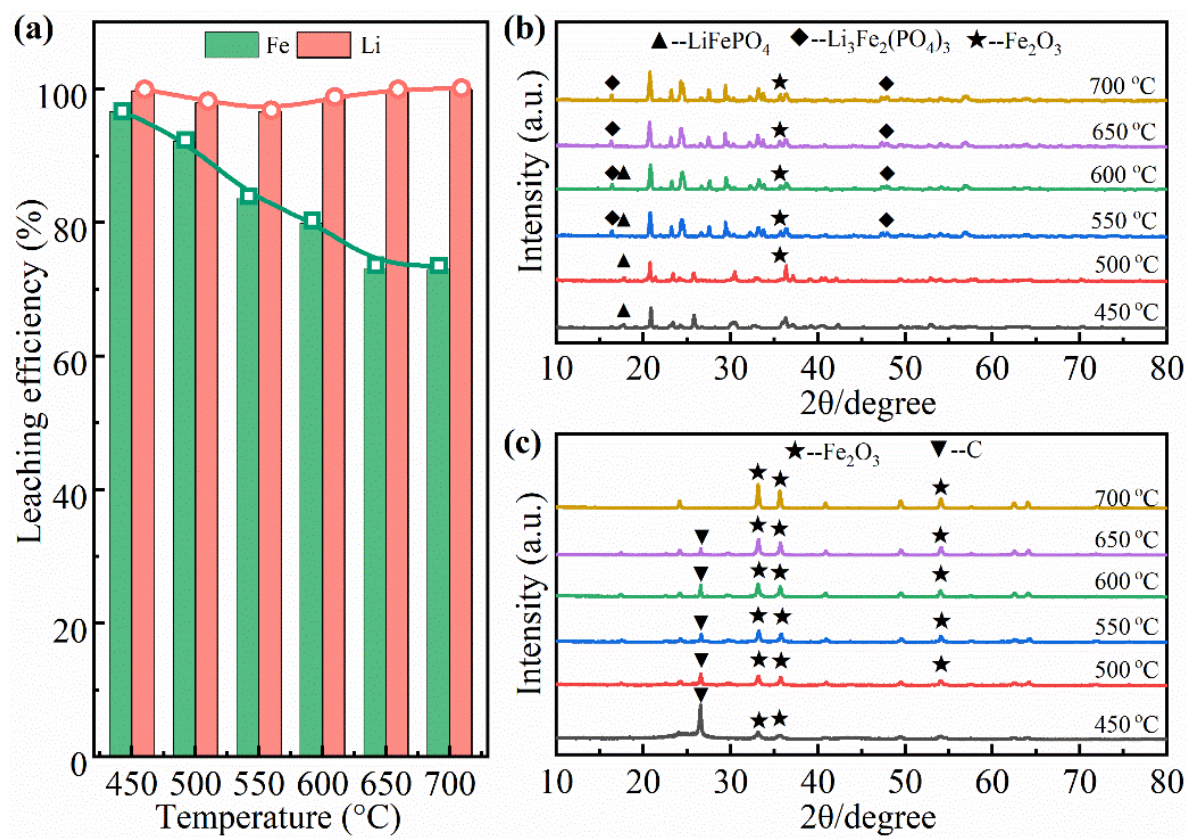

Figure 5. Leaching performance of cathode materials obtained at different roasting temperatures under the leaching conditions of $1.0 \mathrm{M} \mathrm{H}_{2} \mathrm{SO}_{4}, \mathrm{~S} / \mathrm{L}=25 \mathrm{~g} / \mathrm{L}, 70{ }^{\circ} \mathrm{C}$, and $60 \mathrm{~min}$. (a) Leaching efficiencies of $\mathrm{Fe}$ and $\mathrm{Li}$; (b) XRD patterns of calcined cathode materials; (c) XRD patterns of sulfuric acid leaching residue.

Figure $5 \mathrm{~b}$ shows the XRD patterns of cathode materials under different roasting temperatures. The major phases of the cathode materials observed after thermal treatment were $\mathrm{LiFePO}_{4}, \mathrm{Li}_{3} \mathrm{Fe}_{2}\left(\mathrm{PO}_{4}\right)_{3}$ and $\mathrm{Fe}_{2} \mathrm{O}_{3}$. It is consistent with the XRD analysis results in Zheng et al. [29] and Ni et al. [34]. At temperatures below $600{ }^{\circ} \mathrm{C}$, the cathode materials were gradually oxidized to $\mathrm{Li}_{3} \mathrm{Fe}_{2}\left(\mathrm{PO}_{4}\right)_{3}$ and $\mathrm{Fe}_{2} \mathrm{O}_{3}$. At $600{ }^{\circ} \mathrm{C}$, the $\mathrm{LiFePO}_{4}$ phase disappeared completely, proving that most of the cathode materials were oxidized. As the temperature further increased, the diffraction peak of both $\mathrm{Li}_{3} \mathrm{Fe}_{2}\left(\mathrm{PO}_{4}\right)_{3}$ and $\mathrm{Fe}_{2} \mathrm{O}_{3}$ slowly increased. Based on the above results, the oxidation of $\mathrm{LiFePO}_{4}$ cathode materials can be presented as follow Equation (4) [29,34,35].

$$
12 \mathrm{LiFePO}_{4}+3 \mathrm{O}_{2} \rightarrow 4 \mathrm{Li}_{3} \mathrm{Fe}_{2}\left(\mathrm{PO}_{4}\right)_{3}+2 \mathrm{Fe}_{2} \mathrm{O}_{3}
$$

The XRD patterns of sulfuric acid leaching residue of cathode materials shown in Figure $5 c$ clearly indicate that the major phases were $\mathrm{Fe}_{2} \mathrm{O}_{3}$ and $\mathrm{C}$. Compared to Figure $5 \mathrm{~b}$, the phases of $\mathrm{LiFePO}_{4}$ and $\mathrm{Li}_{3} \mathrm{Fe}_{2}\left(\mathrm{PO}_{4}\right)_{3}$ disappeared. This demonstrated that the crystalline structure of cathode materials disintegrated and water-soluble sulfates of $\mathrm{Li}$ and $\mathrm{Fe}$ formed. In addition, the existence of the phase of $\mathrm{Fe}_{2} \mathrm{O}_{3}$ implied that the ferric oxide with high valence was hard to be reduced. It is also notable that the diffraction peaks of $\mathrm{C}$ decreased with the increase of roasting temperature, until they disappeared at $700{ }^{\circ} \mathrm{C}$, where the binder was removed completely. Different from $\mathrm{C}$, the diffraction peaks of $\mathrm{Fe}_{2} \mathrm{O}_{3}$ gradually increased, consistent with the decreased leaching efficiency of Fe in Figure 5 a.

Based on the above results, $500{ }^{\circ} \mathrm{C}$ was selected as the optimum roasting temperature for subsequent experiments exploring the effect of oxygen concentration.

\subsection{Effect of Oxygen Concentration}

The relationship between oxygen concentration and oxidizing roasting process of spent LFPBs plates is another important research object. The experiment was set up with a constant roasting temperature of $500{ }^{\circ} \mathrm{C}$, a gas flow rate of $300 \mathrm{~mL} / \mathrm{min}$, and a roasting time of $30 \mathrm{~min}$. As presented in Figure 6 , the oxygen concentration is closely related to the oxidizing roasting of spent cathode plates. Figure $6 \mathrm{a}_{1}-\mathrm{e}_{1}$, clearly reveal the color change of cathode materials, indicating that the increased oxygen concentration accelerated the oxidation of cathode materials. The changes in $\mathrm{Al}$ foils obtained by 
screening are shown in Figure $6 \mathrm{a}_{2}-\mathrm{e}_{2}$. Some cathode materials still attached to the Al foils at 0 vol. $\%$ (Nitrogen atmosphere) oxygen concentration. As the oxygen concentration rose from 5 vol.\% to 50 vol.\%, the cathode materials were completely peeled from the Al foils. The possible explanation is that oxygen sped up the oxidative decomposition of binder PVDF. Similar changes were observed when investigating the micromorphology of $\mathrm{Al}$ foils (Figure $6 \mathrm{a}_{3}-\mathrm{e}_{3}$ ). The SEM images reveal that as the oxygen concentration increased, the residual binder PVDF and $\mathrm{LiFePO}_{4}$ cathode materials gradually reduced and totally disappeared when the oxygen concentration reached 50 vol.\%.

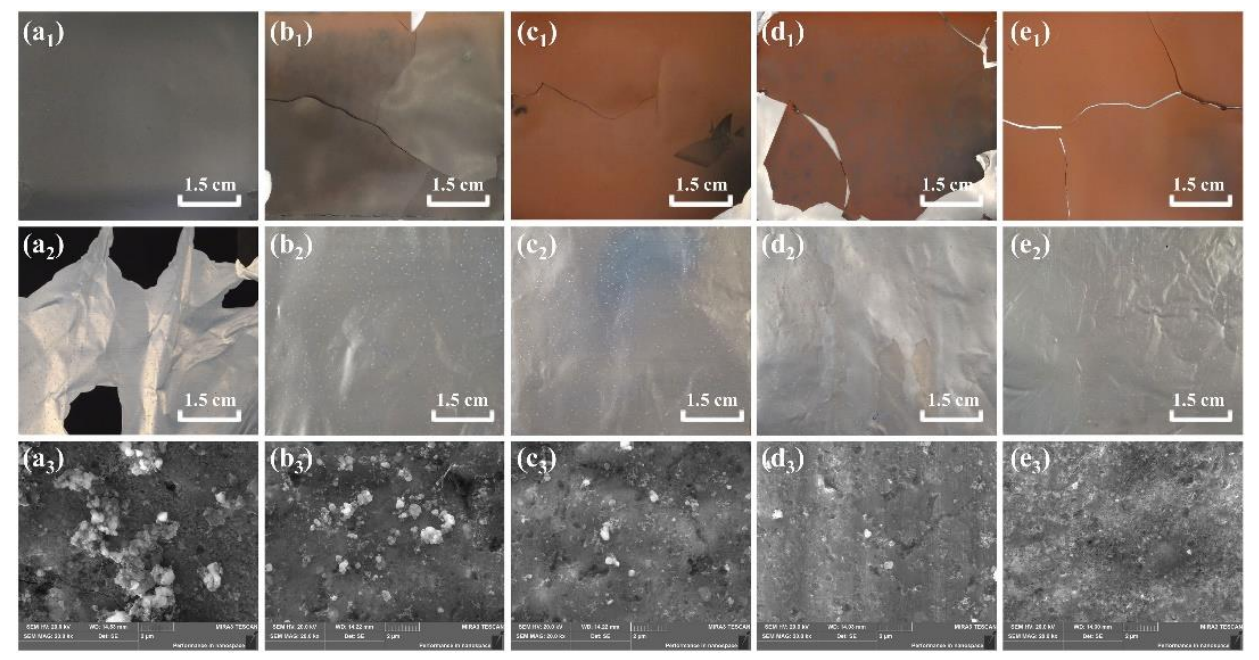

Figure 6. Effect of oxygen concentration on spent $\mathrm{LiFePO}_{4}$ cathode plates: $\left(\mathbf{a}_{1}-\mathbf{e}_{\mathbf{1}}\right)$ Images of cathode plates at $0-50$ vol. $\%$ oxygen concentration; $\left(\mathbf{a}_{2}-\mathbf{e}_{2}\right)$ Images of Al foils at 0-50 vol.\% oxygen concentration; $\left(\mathbf{a}_{3}-\mathbf{e}_{3}\right)$ SEM images of $\mathrm{Al}$ foils at $0-50$ vol.\% oxygen concentration.

The recovery efficiency of cathode materials and the weight loss rate of cathode plates under different oxygen concentrations are shown in Figure 7a. The recovery efficiency of cathode materials rose sharply from $77 \%$ to $99.9 \%$ when the oxygen concentration increased from 0 vol. $\%$ to 5 vol. $\%$. When the oxygen concentration exceeded 5 vol.\%, the recovery efficiency reached about $100 \%$. A slight decrease (11.09-11.02\%) in the weight loss rate was detected when the oxygen concentration increased from 0 vol. $\%$ to 5 vol.\% because the mass of introduced oxygen was greater than the volatilization and decomposition mass of organic compounds. However, the weight loss rate tended to increase continuously when the oxygen concentration exceeded 5 vol.\%. The effects of oxygen concentration on the element content in calcined cathode materials are presented in Figure $7 \mathrm{~b}$. Figure A2 in Appendix A presents the detailed information regarding the chemical compositions of calcined cathode materials. The content of $\mathrm{P}, \mathrm{Fe}$, and $\mathrm{Li}$ changed around $18.0 \%, 33.0 \%$, and $4.0 \%$, respectively. Both the $\mathrm{C}$ and $\mathrm{F}$ content declined with the increase of oxygen concentration, but the Al content behaved in an opposite way $(0.032 \%$ to $0.042 \%)$. This behavior can be reasoned by the intensified oxidative decomposition of binder PVDF resulting in decreased C and F content, while simultaneously increasing the $\mathrm{Al}$ content due the release of corrosive fluorine-containing gases. 
(a)

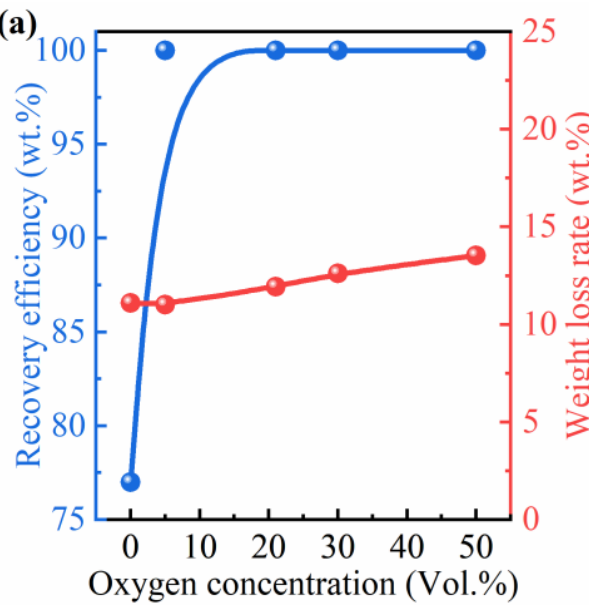

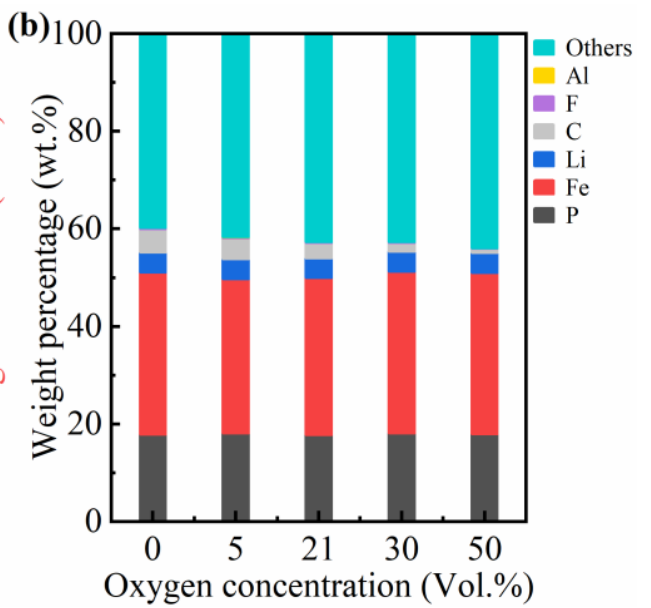

Figure 7. Effect of oxygen concentration on (a) recovery efficiency of cathode materials, weight loss rate of cathode plates, and (b) element content in calcined cathode materials.

The leaching behavior of cathode materials obtained from different oxygen concentrations was further analyzed using ICP-OES and XRD tests. As depicted in Figure 8a, the Li leaching efficiency remained constant at around $100 \%$, while the leaching efficiency of Fe decreased from $98.01 \%$ to $79.9 \%$ as the oxygen concentration increased. The phase composition of calcined cathode materials and sulfuric acid leaching residue were also analyzed at different air flow rates. The oxygen concentration was closely associated with the phase change of cathode materials (Figure $8 b$ ). At 0 vol.\% oxygen concentration, the only phase that existed was $\mathrm{LiFePO}_{4}$. With the increase of oxygen concentration, the diffraction peaks of $\mathrm{Li}_{3} \mathrm{Fe}_{2}\left(\mathrm{PO}_{4}\right)_{3}$ and $\mathrm{Fe}_{2} \mathrm{O}_{3}$ appeared and kept increasing. The $\mathrm{LiFePO}_{4}$ peaks gradually faded away when the oxygen concentration was over 21 vol.\%. Compared to the calcined cathode materials, $\mathrm{LiFePO}_{4}$ and $\mathrm{Li}_{3} \mathrm{Fe}_{2}\left(\mathrm{PO}_{4}\right)_{3}$ disappeared and the major phases were $\mathrm{Fe}_{2} \mathrm{O}_{3}, \mathrm{C}$, and $\mathrm{Fe}_{3}\left(\mathrm{PO}_{4}\right)_{2}$ in sulfuric acid leaching residue (Figure 8c).
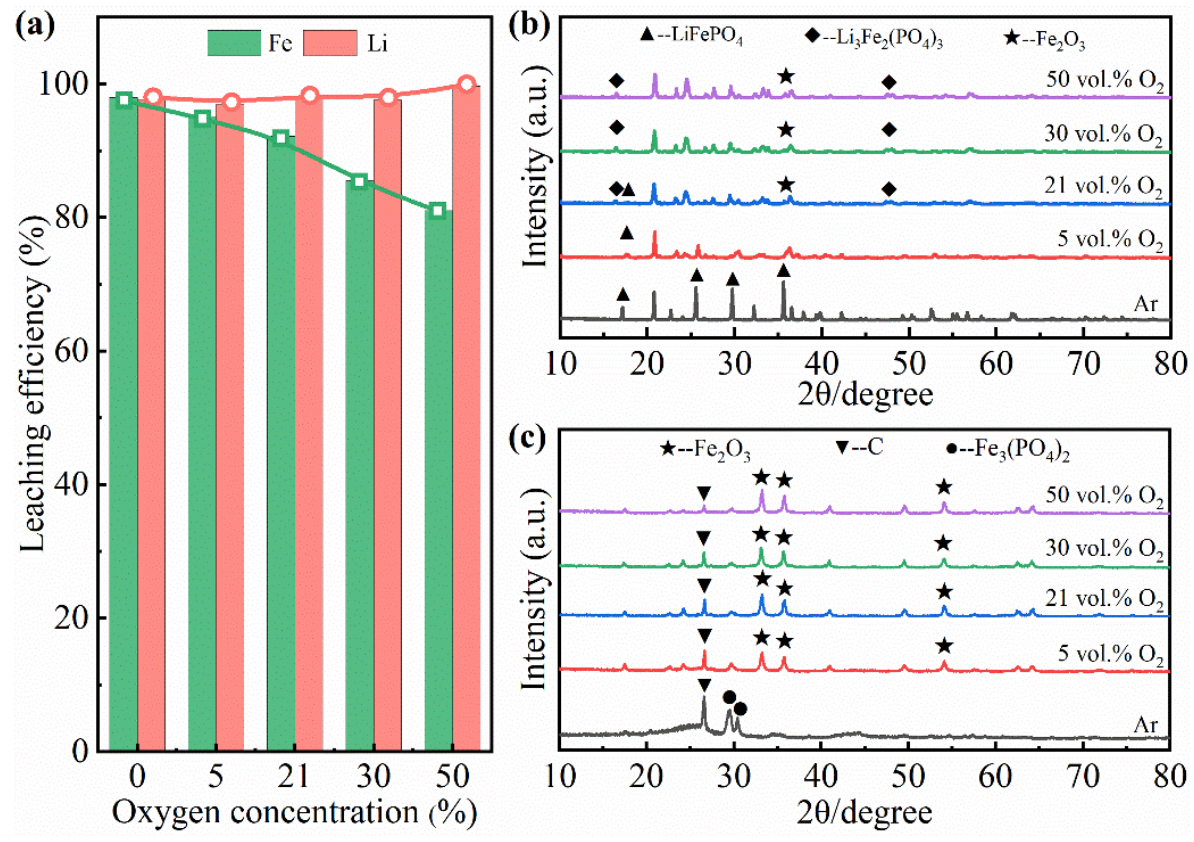

Figure 8. Leaching performance of cathode materials obtained at different oxygen concentrations under the leaching conditions of $1.0 \mathrm{M} \mathrm{H}_{2} \mathrm{SO}_{4}, \mathrm{~S} / \mathrm{L}=25 \mathrm{~g} / \mathrm{L}, 70{ }^{\circ} \mathrm{C}$, and $60 \mathrm{~min}$. (a) Leaching efficiencies of $\mathrm{Fe}$ and $\mathrm{Li}$; (b) XRD patterns of calcined cathode materials; (c) XRD patterns of sulfuric acid leaching residue. 
On the basis of the above findings, 21 vol. $\% \mathrm{O}_{2}$ was considered to be the optimum oxygen concentration for the experiments investigating the effect of gas flow.

\subsection{Effect of Gas Flow}

The last research object related to the oxidizing roasting process of spent $\mathrm{LiFePO}_{4}$ cathode plates was gas flow. The experiment was conducted under a roasting temperature of $500{ }^{\circ} \mathrm{C}$ and an oxygen concentration of 21 vol.\%. As seen in Figure $9 a_{1}-a_{3}$, the cathode materials were grey when the air flow rate was $20 \mathrm{~mL} / \mathrm{min}$. Residual binders and cathode materials adhered to the surface of $\mathrm{Al}$ foils. As the air flow rate increased to $150 \mathrm{~mL} / \mathrm{min}$, the cathode materials became dark brown (Figure $9 b_{1}$ ), suggesting that part of cathode materials was oxidized. In addition, there were less binder and cathode materials adhered to $\mathrm{Al}$ foil (Figure $9 \mathrm{~b}_{2}, \mathrm{~b}_{3}$ ). When the air flow rate reached $300 \mathrm{~mL} / \mathrm{min}$, the cathode materials turned darker brown (Figure $9 c_{1}$ ) and were entirely stripped off from the Al foil (Figure $9 c_{2}$ ). The corresponding SEM image (Figure $9 \mathrm{c}_{3}$ ) indicates that only a limited amount of cathode materials was left. At an air flow rate of $450 \mathrm{~mL} / \mathrm{min}$, most of the cathode materials were oxidized (Figure $9 \mathrm{~d}_{1}$ ), and the binder and cathode materials thoroughly vanished from the $\mathrm{Al}$ foil (Figure $9 \mathrm{~d}_{2}, \mathrm{~d}_{3}$ ).

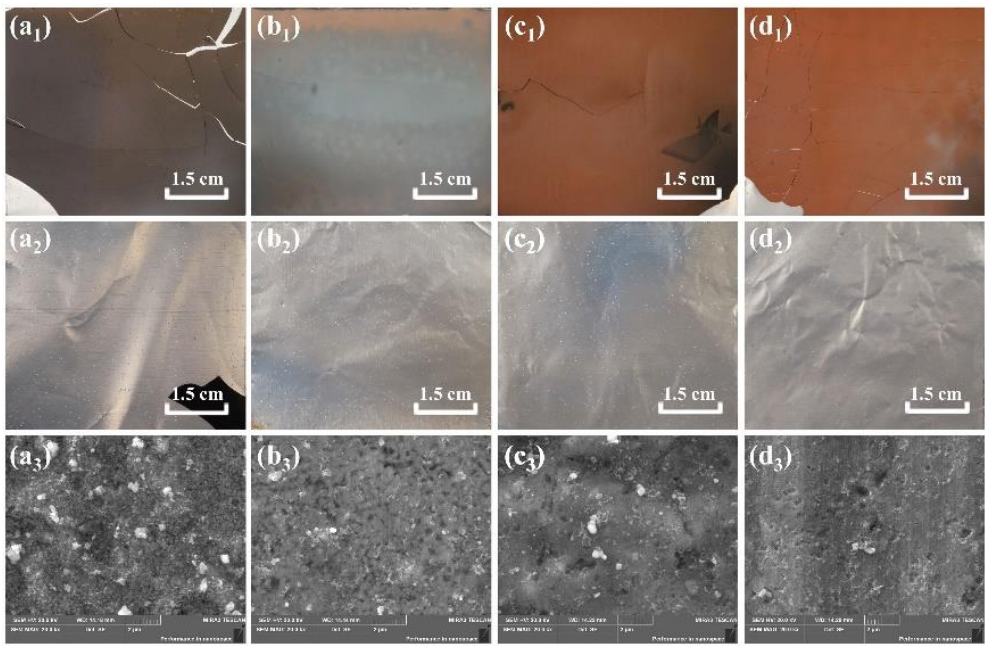

Figure 9. Effect of air flow on spent LFP cathode plates: $\left(\mathbf{a}_{\mathbf{1}}-\mathbf{d}_{\mathbf{1}}\right)$ Images of cathode plates at an air flow rate of $20-450 \mathrm{~mL} / \mathrm{min} ;\left(\mathbf{a}_{2}-\mathbf{d}_{2}\right)$ images of Al foils at an air flow rate of $20-450 \mathrm{~mL} / \mathrm{min} ;\left(\mathbf{a}_{3}-\mathbf{d}_{3}\right)$ SEM images of $\mathrm{Al}$ foils at an air flow rate of $20-450 \mathrm{~mL} / \mathrm{min}$.

The recovery efficiency of cathode materials and the weight loss rate of spent $\mathrm{LiFePO}_{4}$ cathode plates at different air flow rates estimated during the experiment are presented in Figure 10a. As the air flow rate increased from $20 \mathrm{~mL} / \mathrm{min}$ to $150 \mathrm{~mL} / \mathrm{min}$, the recovery efficiency of cathode materials rose by around $5.0 \%$ (from $95 \%$ to $99.9 \%$ ) and the weight loss rate increased from $11.05 \%$ to $13.33 \%$. When the air flow rate exceeded $150 \mathrm{~mL} / \mathrm{min}$, the cathode materials remained a high recovery efficiency (about $100 \%$ ) and the weight loss rate of spent LFPBs cathode plates showed an increase trend (11.05-13.33\%). The effects of air flow on the element content in calcined cathode materials are illustrated in Figure 10b. Their chemical compositions are shown in Appendix A, Figure A3.

Temperature had little effect on the content of $\mathrm{P}, \mathrm{Fe}$, and $\mathrm{Li}$, which kept around $18.0 \%, 32.0 \%$, and $4.0 \%$, respectively. The $\mathrm{Al}$ content also increased $(0.034-0.0415 \%)$, due to the corrosion of fluorine-containing gases. Conversely, the $\mathrm{C}$ content decreased from $4.65 \%$ to $1.26 \%$, and the $\mathrm{F}$ content decreased from $0.25 \%$ to $0.078 \%$. This denotes that the increase of air flow rate accelerated the oxidative decomposition of binder. 
(a)

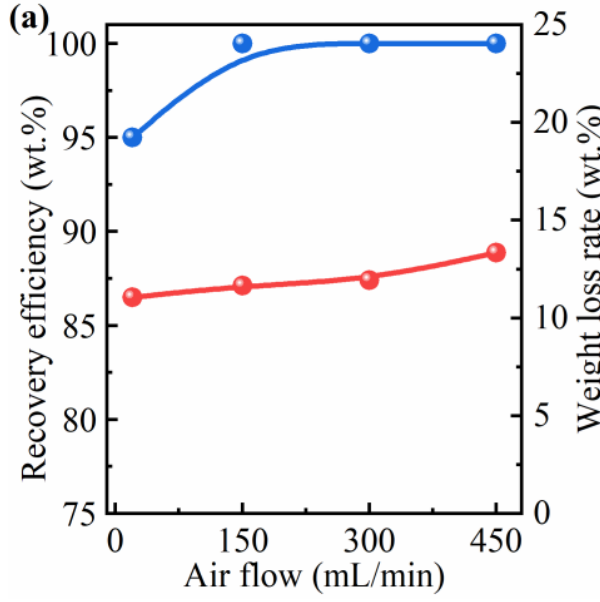

(b) 1

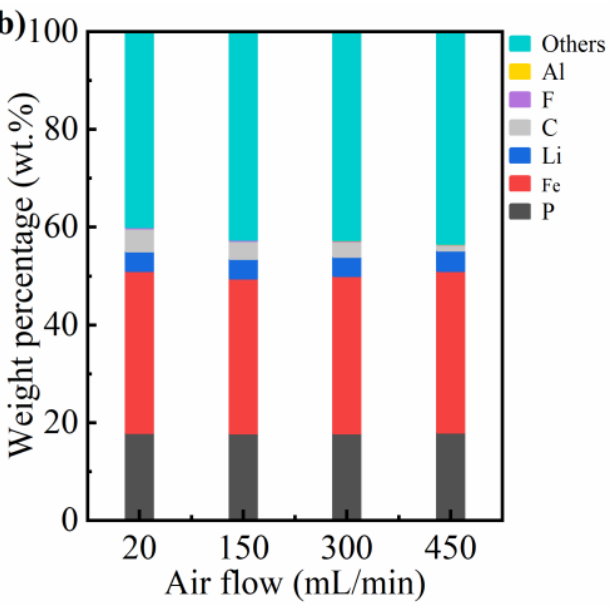

Figure 10. Effect of air flow on the (a) recovery efficiency of cathode materials, weight loss rate of cathode plates, and (b) element content in calcined cathode materials.

Figure 11a shows the leaching efficiencies of Fe and Li acquired at different air flow rate in the sulfuric acid leaching system. The leaching efficiency of Li was quite stable (over 97\%), but that of Fe decreased drastically from $97.12 \%$ to $79.5 \%$ with the increase of air flow rate. The XRD patterns of cathode materials (Figure 11b) were also analyzed for the different air flow rates. At $20 \mathrm{~mL} / \mathrm{min}$, A small amount of cathode materials were oxidized and the major phases of cathode materials were $\mathrm{LiFePO}_{4}$ and $\mathrm{Li}_{3} \mathrm{Fe}_{2}\left(\mathrm{PO}_{4}\right)_{3}$. As the air flow rate increased to $150 \mathrm{~mL} / \mathrm{min}$, a new $\mathrm{Fe}_{2} \mathrm{O}_{3}$ phase appeared. Further, the diffraction peaks of $\mathrm{Li}_{3} \mathrm{Fe}_{2}\left(\mathrm{PO}_{4}\right)_{3}$ increased compared to previous ones. When the air flow rate rose to $450 \mathrm{~mL} / \mathrm{min}$, a continuous growth of diffraction peaks of $\mathrm{Li}_{3} \mathrm{Fe}_{2}\left(\mathrm{PO}_{4}\right)_{3}$ and $\mathrm{Fe}_{2} \mathrm{O}_{3}$ was observed. Figure 11c shows the XRD patterns of the leaching residue. The major phases observed were $\mathrm{Fe}_{2} \mathrm{O}_{3}$ and $\mathrm{C}$. The diffraction peaks of $\mathrm{Fe}_{2} \mathrm{O}_{3}$ increased as the air flow rate increased, which was consistent with the leaching efficiency of Fe.
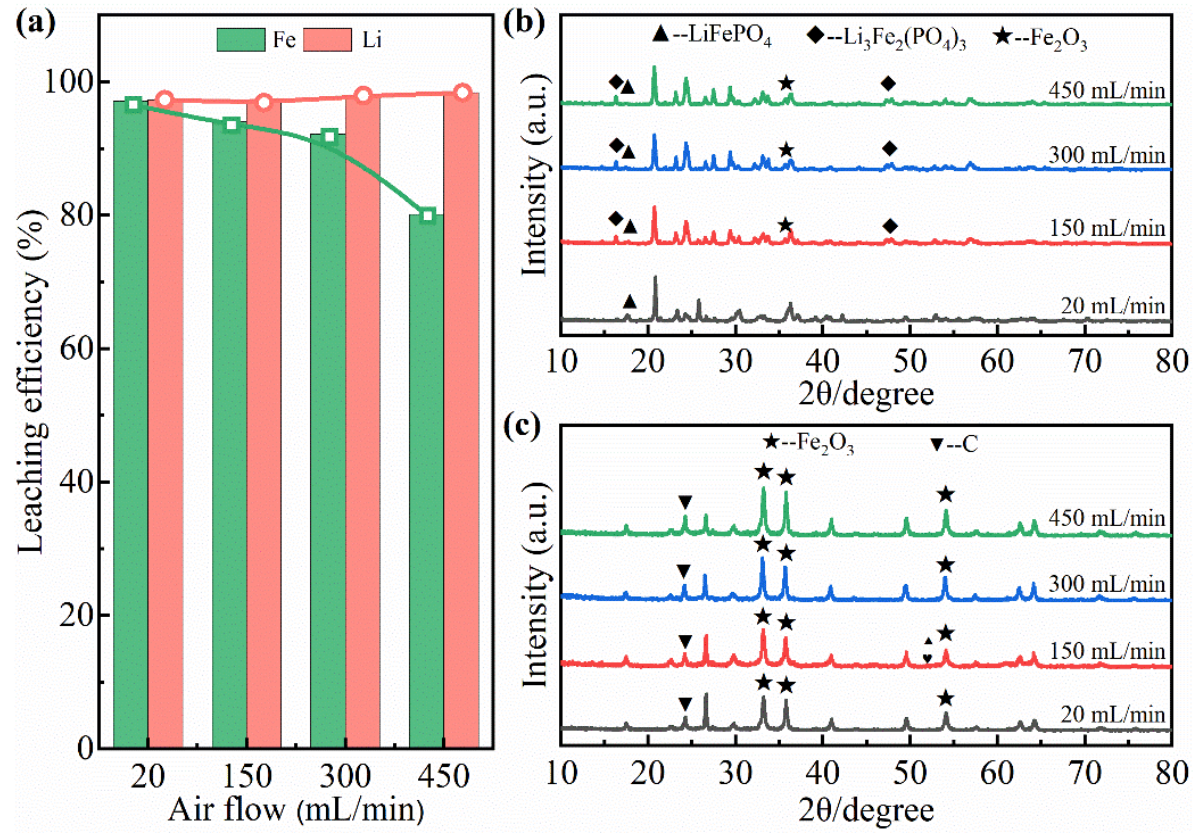

Figure 11. Leaching performance of cathode materials obtained at different air flow under the leaching conditions of $1.0 \mathrm{M} \mathrm{H}_{2} \mathrm{SO}_{4}, \mathrm{~S} / \mathrm{L}=25 \mathrm{~g} / \mathrm{L}, 70{ }^{\circ} \mathrm{C}$, and $60 \mathrm{~min}$. (a) Leaching efficiencies of $\mathrm{Fe}$ and $\mathrm{Li}$; (b) XRD patterns of calcined cathode materials; (c) XRD patterns of sulfuric acid leaching residue. 
Taking the results into account, thereupon, $300 \mathrm{~mL} / \mathrm{min}$ was regarded as the optimum air flow rate for the oxidizing roasting experiment.

\subsection{Characterization of Cathode Materials}

Based on the above experiments, the optimum conditions for the thermal treatment of cathode plates can be summarized as follows: a roasting temperature of $500{ }^{\circ} \mathrm{C}$, an oxygen concentration of $21 \%$ and an air flow rate of $300 \mathrm{~mL} / \mathrm{min}$. When studying the characterization of materials under these circumstances, more findings surfaced. Figure 12a is an SEM micro-morphology of raw cathode materials that was separated from Al foil. Despite the irregular morphologies, the primary particles were highly agglomerated because of the binder. Points 1 and 2 were further analyzed using EDS. The data obtained indicated that the cathode materials were mainly composed of C, O, F, P, and Fe. More specifically, the mole fractions of $\mathrm{C}$ and $\mathrm{F}$ were $12.0 \%$ and $3.5 \%$, respectively, hinting that large amounts of fluorocarbon materials (e.g., binder PVDF and conductive additives) were present in the cathode materials. In contrast to the raw cathode materials, the cathode materials calcined under the predetermined optimal conditions (Figure 12b) showed much less degree of agglomeration. In addition, the large grains were covered with a variety of small irregular and rough particles, which turned out to be $\mathrm{O}, \mathrm{P}$, and Fe in EDS analysis. The $\mathrm{C}$ and F content fell sharply. The differences can be attributed to the oxidative decomposition of binder PVDF during the thermal treatment.

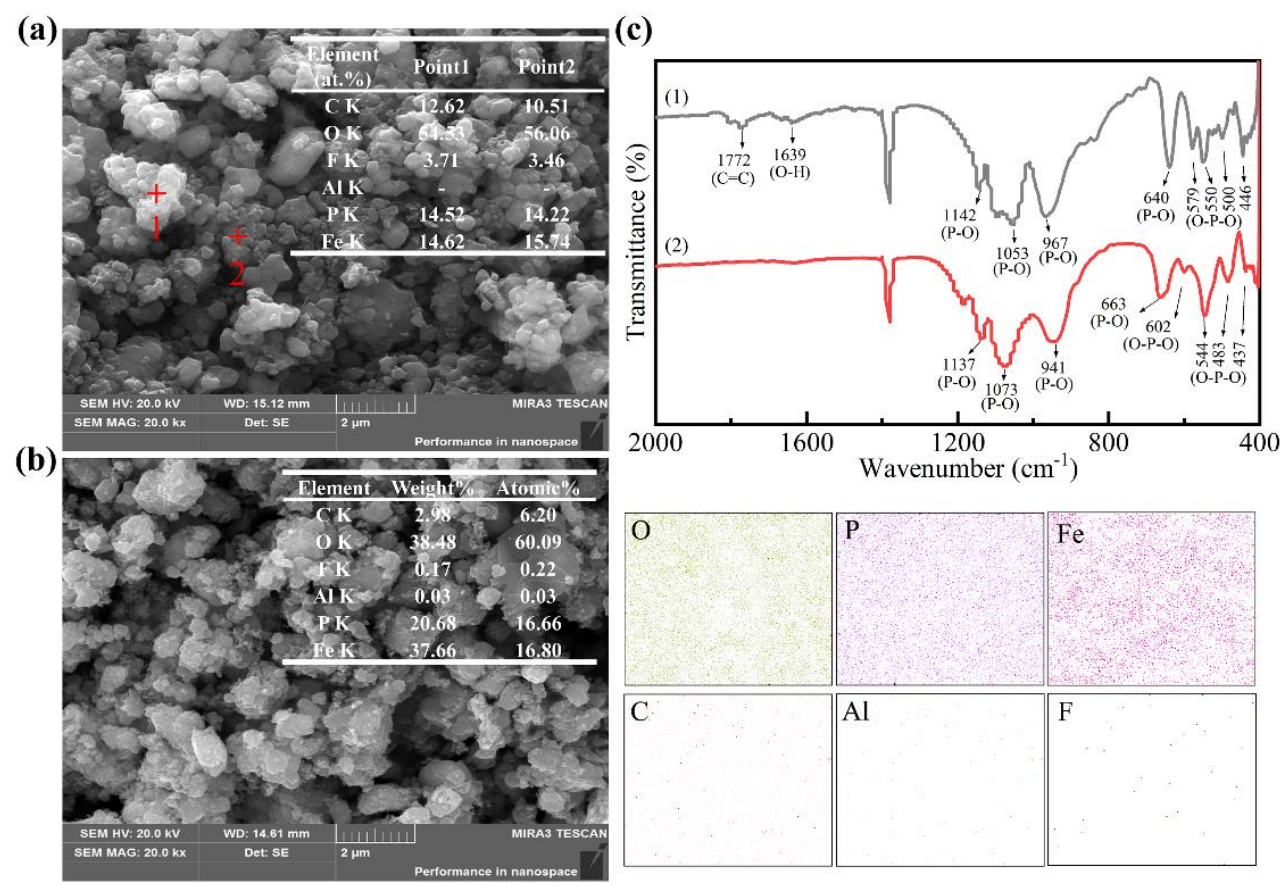

Figure 12. SEM-EDS and FT-IR spectra of raw cathode materials and calcined cathode materials under optimized condition. (a) SEM image of raw cathode materials; (b) SEM image of calcine cathode materials; (c) FT-IR spectra of raw cathode materials and calcined cathode materials.

The differences in the molecular structure and composition of raw and calcined cathode materials were further investigated using FT-IR tests. Figure 12c depicts the distinct changes of the bending and stretching vibrations of cathode materials before and after oxidizing roasting. The raw cathode materials show the absorption peaks at $1639 \mathrm{~cm}^{-1}$ and $1772 \mathrm{~cm}^{-1}$ disappeared. The band around $1639 \mathrm{~cm}^{-1}$ represents the characteristic of $\mathrm{O}-\mathrm{H}$ stretching vibration in $\mathrm{H}_{2} \mathrm{O}$ molecule generated due to the condensation of water in air [28]. The peak around $1772 \mathrm{~cm}^{-1}$ corresponds to the characteristic $\mathrm{C}=\mathrm{C}$ stretching vibration of the polymer $\left(\mathrm{H}_{2} \mathrm{C}=\mathrm{CF}-\mathrm{R}\right)[32,36]$. These peaks are clearly absent in the calcined cathode materials, indicating that the binder was removed in the heating process. The characteristic 
phosphate group vibrations at the wavenumbers $940-1250 \mathrm{~cm}^{-1}$ and $400-700 \mathrm{~cm}^{-1}$ correspond to the asymmetric stretching vibrations of $-\mathrm{PO}_{4}$ tetrahedron and the bending vibrations of O-P-O, respectively, remain unchanged. Those indicate that the cathode materials still existed as phosphates even after the oxidizing roasting process $[37,38]$.

XPS analysis was used to further investigate the changes of surface chemical composition in the raw cathode materials and the calcined cathode materials. The results were shown in Figure 13. The full XPS spectra of cathode materials before and after annealing are shown in Figure 13a. It can be observed that C, F, O, P, and Fe were the main element compositions in the cathode materials. The high contents of $\mathrm{F}$ and $\mathrm{C}$ in raw cathode materials indicated that $\mathrm{LiFePO}_{4}$ particles were cladded by PVDF. After oxidizing roasting, the content of $\mathrm{C}$ and $\mathrm{O}$ decreased from $45.47 \%, 36.77 \%$ to $22.68 \%$, $0.46 \%$, respectively, while the content of O increased from $36.77 \%$ to $54.42 \%$. This demonstrate that the binder PVDF was decomposed effectively and some cathode materials were oxidized. Figure 13b presents the spectrum of the $\mathrm{C}$ ls region. The main peak at $284.7 \mathrm{eV}$ was caused by the carbon black. Two peaks of $\mathrm{C}-\mathrm{OR}$ and $\mathrm{C}=\mathrm{O}$ attributed to organic solvents were detected at 285.5 and $288.9 \mathrm{eV}$ [39]. The peaks located at 286.7 and $291.1 \mathrm{eV}$ are attributed to $\mathrm{CH}_{2}$ and $\left(\mathrm{CF}_{2} \mathrm{CHF}\right)_{\mathrm{n}}$ which are from binder PVDF [40]. After oxidizing roasting, the proportion of peaks derived from organic solvents and binder PVDF decreased significantly, further indicating the decomposition of organic compounds during the oxidizing roasting process is effective. Figure $13 \mathrm{c}$ exhibits the $\mathrm{F} 1 \mathrm{~s}$ spectra before and after oxidizing roasting, the peaks around 685.0 and $686.8 \mathrm{eV}$ correspond to $\mathrm{Li}-\mathrm{F}$ and $\left(-\mathrm{CH}_{2}-\mathrm{CF}_{2}-\right)_{\mathrm{n}}$, which are assigned to binder PVDF and LiF, respectively $[15,40]$. After the reaction, it can be observed that the surface concentration of the fluorine species of the calcined cathode materials was remarkably lowered, but $\mathrm{F}^{-}$ $(686.5 \mathrm{eV})$ and $\mathrm{LiF}$ were still detected. For O 1s, the peaks appeared at 531.7 and $533.3 \mathrm{eV}$ were related to $\mathrm{P}-\mathrm{O}$ and $\mathrm{C}-\mathrm{O}$ coming from the phosphate groups $\left(\mathrm{PO}_{4}{ }^{3-}\right)$ and oxygenated species adsorbed at the surface, respectively [41]. After oxidizing roasting, an additional peak located at $530.3 \mathrm{eV}$ demonstrates the formation of oxidation product $\mathrm{Fe}_{2} \mathrm{O}_{3}$. Figure 13e shows the $\mathrm{P} 2 \mathrm{p}$ spectrum made of two doublets $\left(2 \mathrm{p}_{3 / 2}\right.$ and $\left.2 \mathrm{p}_{1 / 2}\right)$. The first $\mathrm{P} 2 \mathrm{p}$ peak at around $133.7 \mathrm{eV}$ was attributed to $\mathrm{P}-\mathrm{O}$ bonds in phosphate groups and the second one at around $137 \mathrm{eV}$ was related to P-F bonds in $\mathrm{LiPF}_{6}$ [15]. The Fe 2p spectrum in Figure $13 \mathrm{f}$ shows that the spin-orbit doublets of $2 \mathrm{p}_{3 / 2}$ and $2 \mathrm{p}_{1 / 2}$ situated at around 712 and $725 \mathrm{eV}$, respectively. Each of them consists of two main peaks and two satellite peaks, respectively. The peaks at around 710 and $723 \mathrm{eV}$ were assigned to $\mathrm{Fe}(\mathrm{II})$, and the peaks appeared at around 712 and $725.5 \mathrm{eV}$ were related to $\mathrm{Fe}$ (III) [42]. The changes in the proportion of $\mathrm{Fe}(\mathrm{II})$ and $\mathrm{Fe}(\mathrm{III})$ suggest the oxidation of $\mathrm{LiFePO}_{4}$ cathode materials during the oxidizing roasting. 

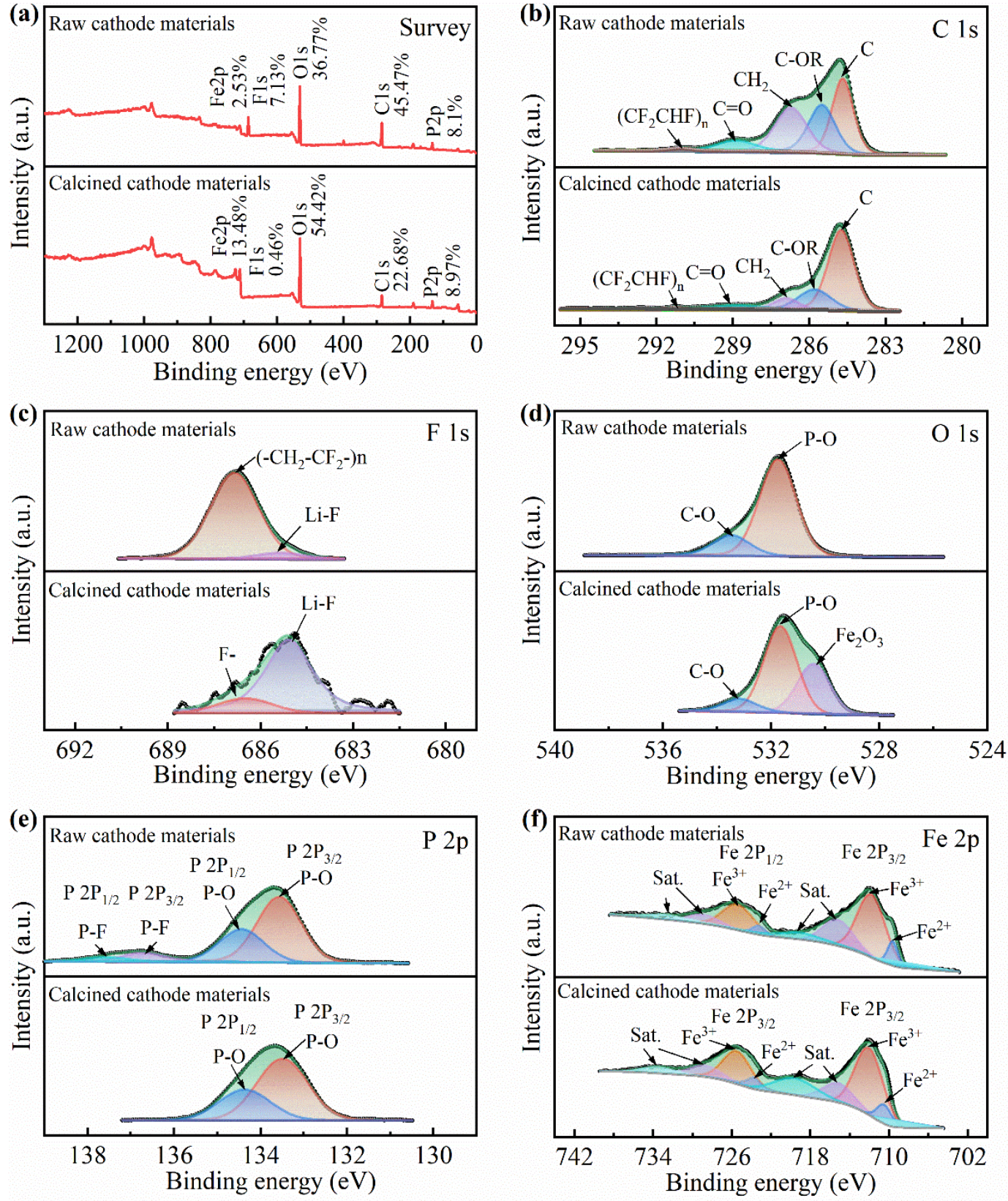

Figure 13. Comparison of (a) the full XPS spectrum, (b) C 1s, (c) F 1s, (d) O 1s, (e) P 2p, and (f) Fe 2p in the raw cathode materials and the calcined cathode materials under optimized condition.

\section{Conclusions}

The oxidizing roasting behavior of spent $\mathrm{LiFePO}_{4}$ cathode plates and leaching performance of cathode materials in sulfuric acid system were investigated systematically in this work. Roasting temperature, oxygen concentration, and air flow rate were detected to obtain the optimum conditions for recovery of spent LFPBs. The key findings of this work are summarized as follows:

(1) When temperature is below $650^{\circ} \mathrm{C}$, the increase of roasting temperature, oxygen concentration, and air flow rate enhanced the liberation of cathode materials. The oxidative decomposition of binder PVDF was intensified. Correspondingly, the $\mathrm{Al}$ content increased slowly but the $\mathrm{C}$ and $\mathrm{F}$ content in the cathode materials decreased sharply.

(2) In general, the cathode materials were gradually oxidized to $\mathrm{Li}_{3} \mathrm{Fe}_{2}\left(\mathrm{PO}_{4}\right)_{3}$ and $\mathrm{Fe}_{2} \mathrm{O}_{3}$ during thermal treatment. The increasing $\mathrm{Fe}_{2} \mathrm{O}_{3}$ led to a slow decline in the leaching rate of $\mathrm{Fe}$ since $\mathrm{Fe}_{2} \mathrm{O}_{3}$ 
cannot be leached effectively in dilute sulfuric acid leaching system. XRD analysis further confirmed that the leaching residue was mainly composed of $\mathrm{Fe}_{2} \mathrm{O}_{3}$ and $\mathrm{C}$.

(3) The SEM-EDS, FT-IR, and XPS analysis indicated that the agglomeration degree of calcined cathode materials was far less than that of raw cathode materials. In addition, the binder PVDF was effectively removed and part of cathode materials were oxidized in the heating process.

(4) Considering the high recovery rate, high leaching rate, few hazardous impurities, and low cost, the optimum conditions for thermal treatment of cathode plates were determined as: roasting temperature $500{ }^{\circ} \mathrm{C}$, oxygen concentration $21 \% \mathrm{O}_{2}$, and air flow rate $300 \mathrm{~mL} / \mathrm{min}$.

Author Contributions: Y.J. contributed to the works of literature search, experimental, figures, data collection, data analysis, and writing and editing; S.Y. contributed to the conceptualization and supervising works; D.Z. contributed to the data collection; Y.L. (Yun Li) contributed to the design of the work. Y.C. played a contributor role of study design, data interpretation, and project administration; Y.L. (Yanqing Lai) contributed the work of review and editing and final approval of the version to be published. All authors have read and agreed to the published version of the manuscript.

Funding: This work was funded by the Hunan Provincial Key Research and Development Projects (Social Development) (Grant No. 2019SK2061).

Conflicts of Interest: The authors declare no conflict of interest.

\section{Appendix A}

The phase composition of cathode materials was examined by XRD (Rigaku, TTR-III, Cu K $\alpha$, Tokyo, Japan) and FT-IR (Nicolet 6700, Thermo Fisher Scientific, Waltham, MA, USA). The surface morphology of cathode materials and Al foils were characterized by SEM (TESCAN MIRA3 LMU, TESCAN ORSAY HOLDING, Brno, The Czech Republic) and EDS (Oxford X-Max20, Oxford Instruments, Oxford, UK). The surface properties of cathode materials were detected by XPS (ESCALAB 250Xi spectrometer, Thermo Scientific, Waltham, MA, USA). The $\mathrm{P}, \mathrm{Fe}, \mathrm{Li}$, and $\mathrm{Al}$ content in cathode materials were examined by inductively coupled plasma-atomic emission spectroscopy (ICP-AES, Optima 5300 DV, Perkin Elmer, Shelton, CT, USA). The C content of cathode materials was characterized by carbon-sulfur analyzer (CS-600, LECO Corporation, St Joseph, MI, USA), and the fluoride ion selective electrode method was employed to measure the $\mathrm{F}$ content of cathode materials.
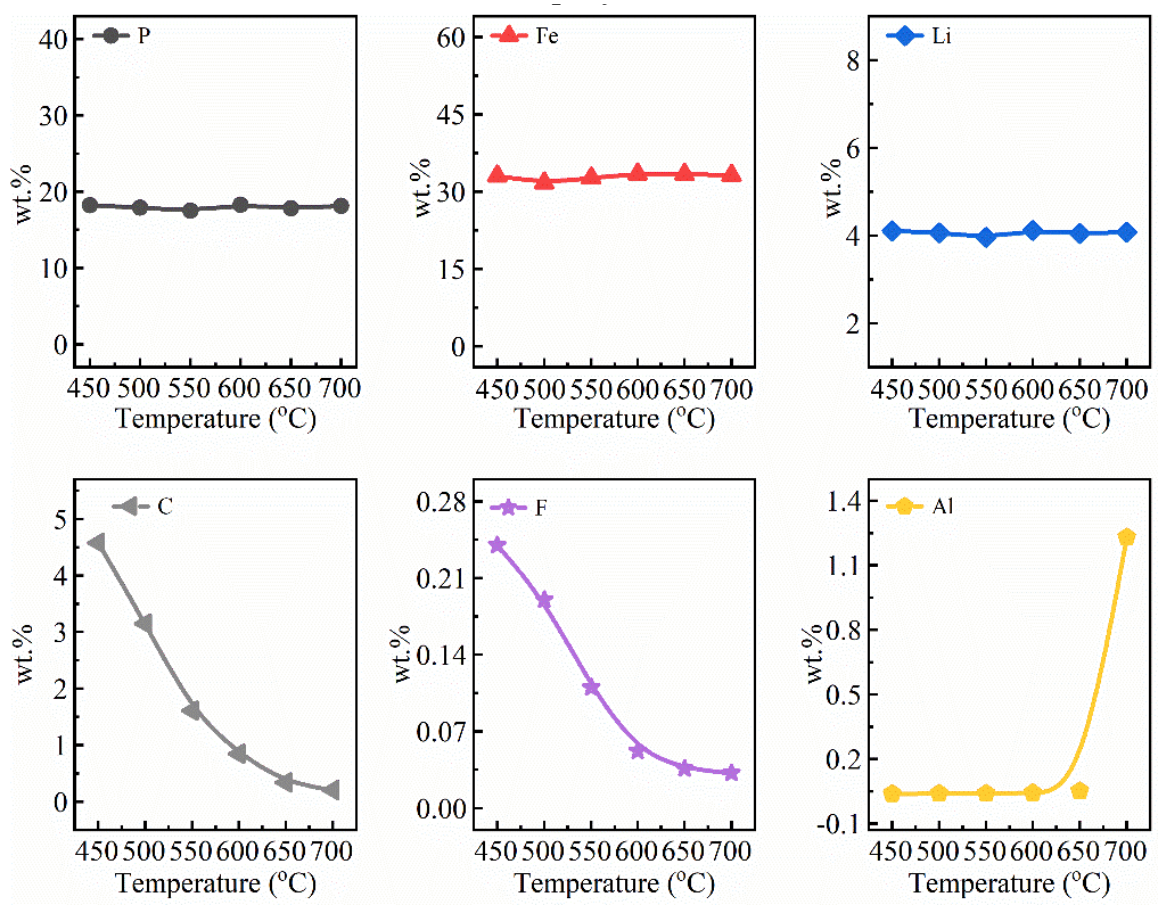

Figure A1. Chemical analysis of calcined cathode materials obtained at different roasting temperatures. 

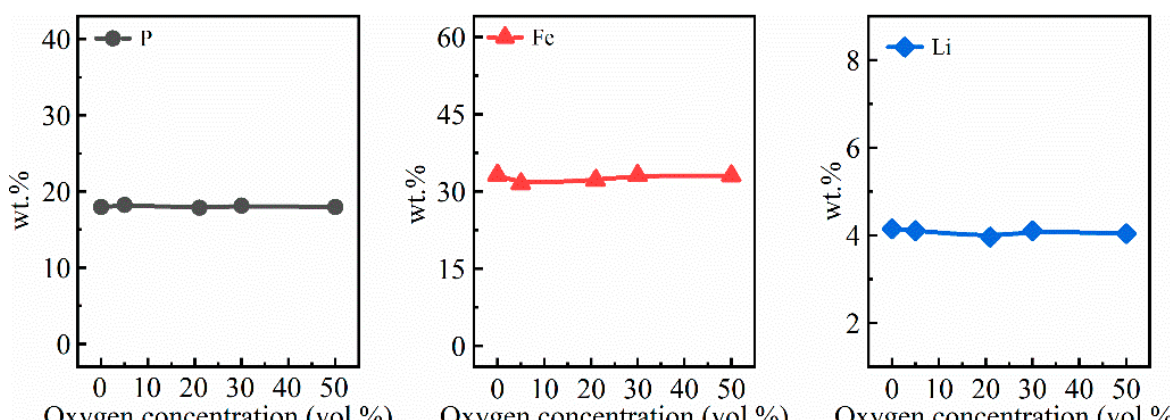

Oxygen concentration (vol.\%)
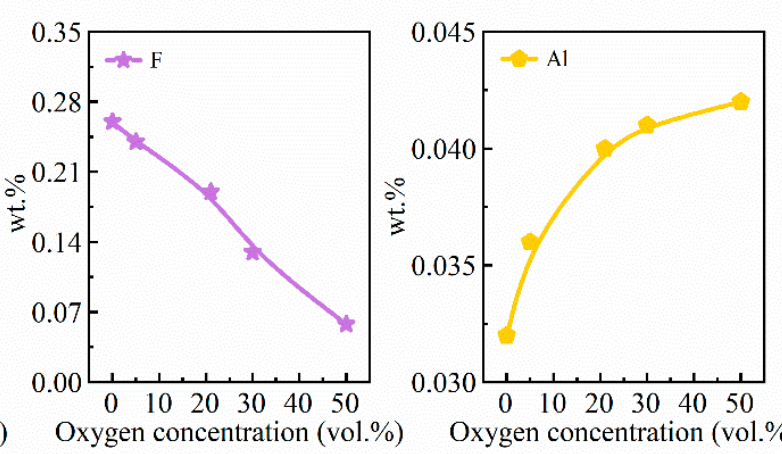

Oxygen concentration (vol.\%)

Oxygen concentration (vol.\%)

Oxygen concentration (vol.\%)

Figure A2. Chemical analysis of calcined cathode materials obtained at different oxygen concentrations.
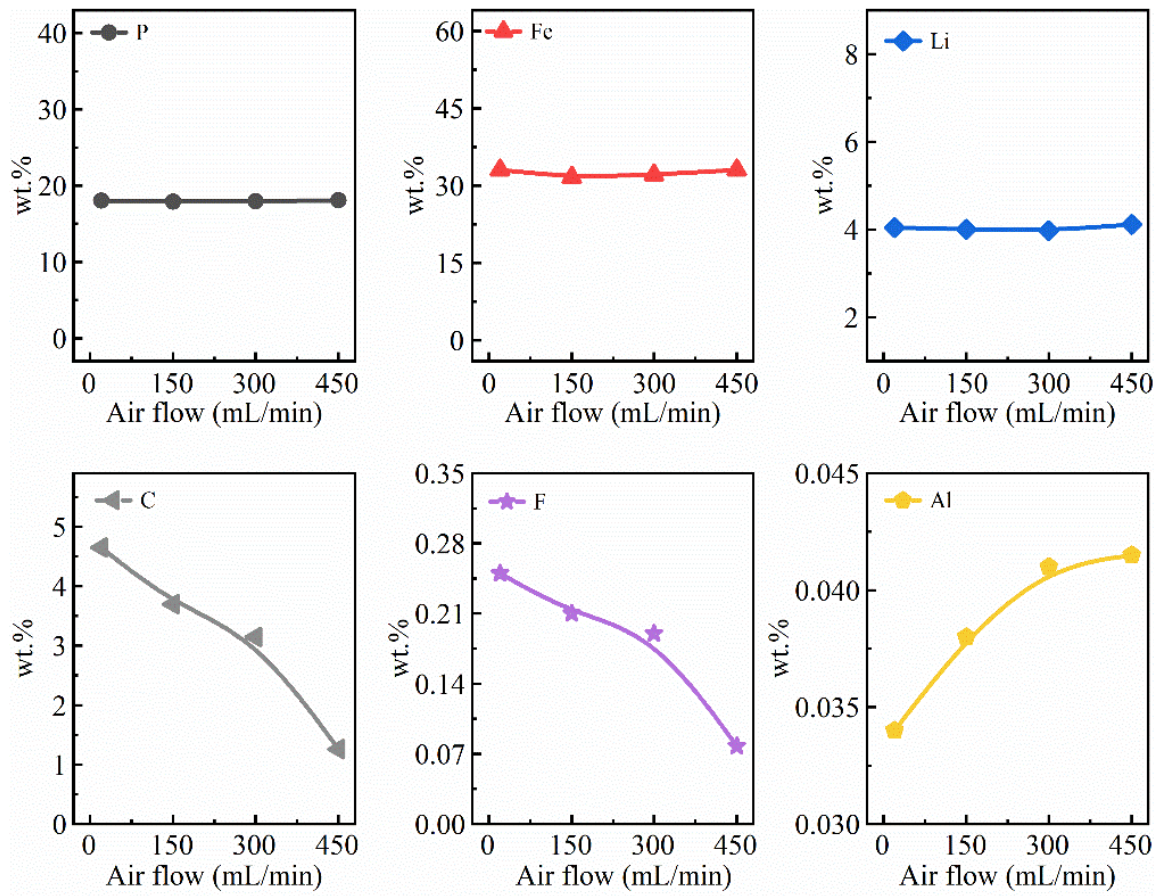

Figure A3. Chemical analysis of calcined cathode materials obtained at different air flow rates.

\section{References}

1. Zou, H.; Gratz, E.; Apelian, D.; Wang, Y. A novel method to recycle mixed cathode materials for lithium ion batteries. Green Chem. 2013, 15, 1183. [CrossRef]

2. Li, L.; Bian, Y.; Zhang, X.; Yao, Y.; Xue, Q.; Fan, E.; Wu, F.; Chen, R. A green and effective room-temperature recycling process of $\mathrm{LiFePO}_{4}$ cathode materials for lithium-ion batteries. Waste Manag. 2019, 85, 437-444. [CrossRef] [PubMed]

3. Wang, W.; Wu, Y. An overview of recycling and treatment of spent $\mathrm{LiFePO}_{4}$ batteries in China. Resour. Conserv. Recy 2017, 127, 233-243. [CrossRef] 
4. Liu, C.; Lin, J.; Cao, H.; Zhang, Y.; Sun, Z. Recycling of spent lithium-ion batteries in view of lithium recovery: A critical review. J. Clean. Prod. 2019, 228, 801-813. [CrossRef]

5. Zeng, X.; Li, J.; Singh, N. Recycling of Spent Lithium-Ion Battery: A Critical Review. Crit. Rev. Environ. Sci. Technol. 2014, 44, 1129-1165. [CrossRef]

6. Heelan, J.; Gratz, E.; Zheng, Z.; Wang, Q.; Chen, M.; Apelian, D.; Wang, Y. Current and Prospective Li-Ion Battery Recycling and Recovery Processes. JOM 2016, 68, 2632-2638. [CrossRef]

7. Huang, B.; Pan, Z.; Su, X.; An, L. Recycling of lithium-ion batteries: Recent advances and perspectives. J. Power Sources 2018, 399, 274-286. [CrossRef]

8. Natarajan, S.; Aravindan, V. Burgeoning Prospects of Spent Lithium-Ion Batteries in Multifarious Applications. Adv. Energy Mater. 2018, 8, 1802303. [CrossRef]

9. Yao, Y.; Zhu, M.; Zhao, Z.; Tong, B.; Fan, Y.; Hua, Z. Hydrometallurgical Processes for Recycling Spent Lithium-Ion Batteries: A Critical Review. ACS Sustain. Chem. Eng. 2018, 6, 13611-13627. [CrossRef]

10. Zeng, X.; Li, J.; Liu, L. Solving spent lithium-ion battery problems in China: Opportunities and challenges. Renew. Sust. Energ. Rev. 2015, 52, 1759-1767. [CrossRef]

11. Lv, W.; Wang, Z.; Cao, H.; Sun, Y.; Zhang, Y.; Sun, Z. A Critical Review and Analysis on the Recycling of Spent Lithium-Ion Batteries. ACS Sustain. Chem. Eng. 2018, 6, 1504-1521. [CrossRef]

12. Zhang, X.; Xie, Y.; Lin, X.; Li, H.; Cao, H. An overview on the processes and technologies for recycling cathodic active materials from spent lithium-ion batteries. J. Mater. Cycles Waste Manag. 2013, 15, 420-430. [CrossRef]

13. Li, J.-H.; Li, X.-H.; Zhang, Y.-H.; Hu, Q.-Y.; Wang, Z.-X.; Zhou, Y.-Y.; Fu, F.-M. Study of spent battery material leaching process. Trans. Nonferrous Met. Soc. China 2009, 19, 751-755. [CrossRef]

14. Zhang, T.; He, Y.; Wang, F.; Ge, L.; Zhu, X.; Li, H. Chemical and process mineralogical characterizations of spent lithium-ion batteries: An approach by multi-analytical techniques. Waste Manag. 2014, 34, 1051-1058. [CrossRef] [PubMed]

15. Zhang, T.; He, Y.; Wang, F.; Li, H.; Duan, C.; Wu, C. Surface analysis of cobalt-enriched crushed products of spent lithium-ion batteries by X-ray photoelectron spectroscopy. Sep. Purif. Technol. 2014, 138, $21-27$. [CrossRef]

16. Yang, L.; Xi, G.; Xi, Y. Recovery of Co, Mn, Ni, and Li from spent lithium ion batteries for the preparation of $\mathrm{LiNi}_{\mathrm{x}} \mathrm{Co}_{\mathrm{y}} \mathrm{Mn}_{\mathrm{z}} \mathrm{O}_{2}$ cathode materials. Ceram. Int. 2015, 41, 11498-11503. [CrossRef]

17. Yao, L.; Feng, Y.; Xi, G. A new method for the synthesis of $\mathrm{LiNi}_{1 / 3} \mathrm{Co}_{1 / 3} \mathrm{Mn}_{1 / 3} \mathrm{O}_{2}$ from waste lithium ion batteries. RSC Adv. 2015, 5, 44107-44114. [CrossRef]

18. Song, X.; Hu, T.; Liang, C.; Long, H.L.; Zhou, L.; Song, W.; You, L.; Wu, Z.S.; Liu, J.W. Direct regeneration of cathode materials from spent lithium iron phosphate batteries using a solid phase sintering method. RSC Adv. 2017, 7, 4783-4790. [CrossRef]

19. Wang, L.; Li, J.; Zhou, H.; Huang, Z.; Tao, S.; Zhai, B.; Liu, L.; Hu, L. Regeneration cathode material mixture from spent lithium iron phosphate batteries. J. Mater. Sci. Mater. Electron. 2018, 29, 9283-9290. [CrossRef]

20. Nan, J.; Han, D.; Zuo, X. Recovery of metal values from spent lithium-ion batteries with chemical deposition and solvent extraction. J. Power Sources 2005, 152, 278-284. [CrossRef]

21. Chen, L.; Tang, X.; Zhang, Y.; Li, L.; Zeng, Z.; Zhang, Y. Process for the recovery of cobalt oxalate from spent lithium-ion batteries. Hydrometallurgy 2011, 108, 80-86. [CrossRef]

22. Chen, J.; Li, Q.; Song, J.; Song, D.; Zhang, L.; Shi, X. Environmentally friendly recycling and effective repairing of cathode powders from spent $\mathrm{LiFePO}_{4}$ batteries. Green Chem. 2016, 18, 2500-2506. [CrossRef]

23. Li, X.; Zhang, J.; Song, D.; Song, J.; Zhang, L. Direct regeneration of recycled cathode material mixture from scrapped $\mathrm{LiFePO}_{4}$ batteries. J. Power Sources 2017, 345, 78-84. [CrossRef]

24. Paulino, J.F.; Busnardo, N.G.; Afonso, J.C. Recovery of valuable elements from spent Li-batteries. J. Hazard. Mater. 2008, 150, 843-849. [CrossRef] [PubMed]

25. Granata, G.; Pagnanelli, F.; Moscardini, E.; Takacova, Z.; Havlik, T.; Toro, L. Simultaneous recycling of nickel metal hydride, lithium ion and primary lithium batteries: Accomplishment of European Guidelines by optimizing mechanical pre-treatment and solvent extraction operations. J. Power Sources 2012, 212, $205-211$. [CrossRef]

26. Hanisch, C.; Loellhoeffel, T.; Diekmann, J.; Markley, K.J.; Haselrieder, W.; Kwade, A. Recycling of lithium-ion batteries: A novel method to separate coating and foil of electrodes. J. Clean. Prod. 2015, 108, 301-311. [CrossRef] 
27. Yang, Y.; Huang, G.; Xu, S.; He, Y.; Liu, X. Thermal treatment process for the recovery of valuable metals from spent lithium-ion batteries. Hydrometallurgy 2016, 165, 390-396. [CrossRef]

28. Lee, C.K.; Rhee, K.-I. Preparation of $\mathrm{LiCoO}_{2}$ from spent lithium-ion batteries. J. Power Sources 2002, 109, 17-21. [CrossRef]

29. Zheng, R.; Zhao, L.; Wang, W.; Liu, Y.; Ma, Q.; Mu, D.; Li, R.; Dai, C. Optimized Li and Fe recovery from spent lithium-ion batteries via a solution-precipitation method. RSC Adv. 2016, 6, 43613-43625. [CrossRef]

30. Ojanen, S.; Lundstrom, M.; Santasalo-Aarnio, A.; Serna-Guerrero, R. Challenging the concept of electrochemical discharge using salt solutions for lithium-ion batteries recycling. Waste Manag. 2018, 76, 242-249. [CrossRef]

31. Liu, W.; Zhong, X.; Han, J.; Qin, W.; Liu, T.; Zhao, C.; Chang, Z. Kinetic Study and Pyrolysis Behaviors of Spent $\mathrm{LiFePO}_{4}$ Batteries. ACS Sustain. Chem. Eng. 2018, 7, 1289-1299. [CrossRef]

32. Chen, X.; Cao, L.; Kang, D.; Li, J.; Zhou, T.; Ma, H. Recovery of valuable metals from mixed types of spent lithium ion batteries. Part II: Selective extraction of lithium. Waste Manag. 2018, 80, 198-210. [CrossRef]

33. Yang, Y.; Meng, X.; Cao, H.; Lin, X.; Liu, C.; Sun, Y.; Zhang, Y.; Sun, Z. Selective recovery of lithium from spent lithium iron phosphate batteries: A sustainable process. Green Chem. 2018, 20, 3121-3133. [CrossRef]

34. Ni, J.; Wang, Y. Temperature-driven structural evolution of carbon modified $\mathrm{LiFePO}_{4}$ in air. RSC Adv. 2015, 5, 30537-30541. [CrossRef]

35. Zhu, S.; Zhou, H.; Miyoshi, T.; Hibino, M.; Honma, I.; Ichihara, M. Self-Assembly of the Mesoporous Electrode Material $\mathrm{Li}_{3} \mathrm{Fe}_{2}\left(\mathrm{PO}_{4}\right)_{3}$ Using a Cationic Surfactant as the Template. Adv. Mater. 2004, 16, 2012-2017. [CrossRef]

36. Sun, L.; Qiu, K. Vacuum pyrolysis and hydrometallurgical process for the recovery of valuable metals from spent lithium-ion batteries. J. Hazard. Mater. 2011, 194, 378-384. [CrossRef]

37. Salah, A.; Jozwiak, P.; Garbarczyk, J.; Benkhouja, K.; Zaghib, K.; Gendron, F.; Julien, C. Local structure and redox energies of lithium phosphates with olivine- and Nasicon-like structures. J. Power Sources 2005, 140, 370-375. [CrossRef]

38. Ravet, N.; Gauthier, M.; Zaghib, K.; Goodenough, J.B.; Mauger, A.; Gendron, F.; Julien, C.M. Mechanism of the $\mathrm{Fe}^{3+}$ reduction at low temperature for $\mathrm{LiFePO}_{4}$ synthesis from a polymeric additive. Chem. Mater. 2007, 19, 2595-2602. [CrossRef]

39. Zhang, G.; He, Y.; Feng, Y.; Wang, H.; Zhu, X. Pyrolysis-Ultrasonic-Assisted Flotation Technology for Recovering Graphite and $\mathrm{LiCoO}_{2}$ from Spent Lithium-Ion Batteries. ACS Sustain. Chem. Eng. 2018, 6, 10896-10904. [CrossRef]

40. Wang, M.; Tan, Q.; Liu, L.; Li, J. Efficient Separation of Aluminum Foil and Cathode Materials from Spent Lithium-Ion Batteries Using a Low-Temperature Molten Salt. ACS Sustain. Chem. Eng. 2019, 7, 8287-8294. [CrossRef]

41. Castro, L.; Dedryvère, R.; Ledeuil, J.B.; Bréger, J.; Tessier, C.; Gonbeau, D. Aging Mechanisms of $\mathrm{LiFePO}_{4} / /$ Graphite Cells Studied by XPS: Redox Reaction and Electrode/Electrolyte Interfaces. J. Electrochem. Soc. 2012, 159, A357-A363. [CrossRef]

42. Castro, L.; Dedryvere, R.; El Khalifi, M.; Lippens, P.E.; Bréger, J.; Tessier, C.; Gonbeau, D. The Spin-Polarized Electronic Structure of $\mathrm{LiFePO}_{4}$ and $\mathrm{FePO}_{4}$ Evidenced by in-Lab XPS. J. Phys. Chem. C 2010, 114, 17995-18000. [CrossRef]

Publisher's Note: MDPI stays neutral with regard to jurisdictional claims in published maps and institutional affiliations.

(C) 2020 by the authors. Licensee MDPI, Basel, Switzerland. This article is an open access article distributed under the terms and conditions of the Creative Commons Attribution (CC BY) license (http://creativecommons.org/licenses/by/4.0/). 